\title{
Optimization of $\mathrm{TiO}_{2}$ nanowires synthesis using hydrothermal method for hydrogen production
}

\author{
I. Kustiningsih ${ }^{1 *}$, Sutinah ${ }^{1}$, M. Stefirizky ${ }^{1}$, Slamet $^{2}$, W. W. Purwanto ${ }^{2}$ \\ ${ }^{1}$ Chemical Engineering Department, Faculty of Engineering, Sultan Ageng Tirtayasa University, \\ Serang, 42118, Indonesia \\ ${ }^{2}$ Chemical Engineering Department, Faculty of Engineering, University of Indonesia, \\ Depok, 16424, Indonesia \\ *indar.kustiningsih@untirta.ac.id
}

\begin{abstract}
Effects of sonication and hydrothermal treatment time on $\mathrm{TiO}_{2}$ nanowires (TNWs) formation have been investigated. Sonication of $\mathrm{TiO}_{2} \mathrm{P} 25$ sol was performed using sonicator water bath Cole for $0.5,1$ and 2 hours followed by hydrothermal treatment. The hydrothermal treatment was carried out in a teflon lined stainless steel autoclave for 12, 15 and 24 hours. The samples were characterized by means of Scanning Electron Microscope (SEM), X-ray powder diffractometer (XRD), UV-vis diffuse and reflectance spectroscopy (UV-vis DRS). The specific surface area of each sample was determined by the BET nitrogen gas adsorption/desorption method. The photocatalytic activity of TNWs was evaluated with photocatalytic $\mathrm{H}_{2}$ evolution from aqueous methanol solution. The result showed that the best TNWs was obtained at $1 \mathrm{hr}$ sonication followed by hydrothermal process for 12 hours. By using this catalyst hydrogen production reached $82 \mu \mathrm{mol}$ after $5 \mathrm{~h}$ while using $\mathrm{TiO}_{2} \mathrm{P} 25$ could only reach $23 \mu \mathrm{mol}$.
\end{abstract}

Keywords: $\quad \mathrm{TiO}_{2}$; nanowires; photocatalytic; hydrogen; Sonication; Hydrothermal

\section{INTRODUCTION}

Hydrogen is well known as one of the alternative clean energy. However, on the earth hydrogen molecules do not form naturally but must be produced from other materials containing hydrogen $[1,2]$. Hydrogen production from photocatalytic water splitting provides a potential opportunity to obtain clean, renewable and storable energy from abundant water using solar energy. Titanium dioxide $\left(\mathrm{TiO}_{2}\right)$ is regarded as a material with excellent photocatalytic activity and has been investigated for water splitting [3-5], photocatalytic activity [6,7] and photovoltaics [8,9]. $\mathrm{TiO}_{2}$ also has high stability, biological and chemical inertness, strong oxidizing power, non-toxicity and long term stability against photo and chemical corrosion [10-14].

In the last years, novel nanostructures such as nanowires [15], nanotubes [4,16-18], and nanorods [19-21] derived from $\mathrm{TiO}_{2}$ have been employed in water splitting [22]. These structures have high specific surface area, ion-exchange and photocatalytic abilities [23,24]. In the last year, new routes to synthesize $\mathrm{TiO}_{2}$ with $1 \mathrm{D}$ structure have been continuously proposed, such as thermal treatment [25], the assisted-template method [26,27], the sol-gel process [28], electrochemical anodic oxidation [4,29-32] and hydrothermal treatment [14-16,24,33,34]. Among these approaches, the hydrothermal treatment is regarded as one of the most efficient methods to synthesize $1 \mathrm{~d} \mathrm{TiO}_{2}$ because it can dramatically decrease the required processing temperature from $850^{\circ} \mathrm{C}$ to $180^{\circ} \mathrm{C}$ 
under a more alkali environment [6]. Beside that this method has high reactivity, low energy requirement, relatively non-polluting set-up and simple control of the aqueous solution [22].

Previous researchers demonstrated that the hydrothermal method can also be applied to prepare $\mathrm{TiO}_{2}$ nanowires but this method required a long reaction time [15,23]. Jitputi et al reported for producing $\mathrm{TiO}_{2} \mathrm{NW}$ by using hydrothermal method needed $75 \mathrm{~h}$ [23]. Therefore, the improvement of the hydrothermal synthesis process by shortening the reaction time is very important. In this study a simple and fast method of combined sonication and hydrothermal treatment is proposed for the production of $\mathrm{TiO}_{2}$ nanowires. The objective of this study is to investigate the effect of sonication process on hydrothermal treatment for the production of $\mathrm{TiO}_{2}$ nanowires, such as morphological structures, photoelectrochemical properties and photocatalytic activity as evidenced by hydrogen production.

\section{METHODS AND MATERIAL}

\section{Synthesis of $\mathrm{TiO}_{2}$ nanowires}

In a typical synthesis, 3 grams of $\mathrm{TiO}_{2}$ Degussa P25 were dispersed in $150 \mathrm{~mL}$ of $10 \mathrm{M} \mathrm{KOH}$ and ultra-sonicated for $0.5 \mathrm{~h}, 1 \mathrm{~h}$ and $2 \mathrm{~h}$ followed hydrothermal process. The hydrothermal process was carried out at temperature of $150^{\circ} \mathrm{C}$ with variation of reaction time for $12 \mathrm{~h}, 15 \mathrm{~h}$ and $24 \mathrm{~h}$. After the hydrothermal treatment, the prepared samples were rinsed well with distilled water then further rinsed with Hydrogen Chloride and distilled water repeatedly until the $\mathrm{pH}$ value of the washing solution was lower than 7 . The $\mathrm{TiO}_{2}$ nanowires were obtained through centrifugation and further dried in a programmable furnace at $150^{\circ} \mathrm{C}$ then calcined at $500^{\circ} \mathrm{C}$.

\section{Characterization of $\mathrm{TiO}_{2}$ nanowires}

The crystal structures of as-synthesized $\mathrm{TiO}_{2}$ nanowires were determined using a Philips $\mathrm{PW} 1710$ $\mathrm{XRD}$ diffractometer with $\mathrm{Cu} \mathrm{K} \alpha$ radiation $\left(\lambda=1.5406 \AA\right.$ at a scan rate of $\left.0.025^{\circ} \mathrm{s}-1\right)$. The crystallite size was calculated using a diffraction peak from Scherre's formula [35]. Morphological observations were performed on a JEOL JSM-6390A scanning electron microscope (SEM) equipped with an energy dispersive X-ray detector. The transmission electron microscopy (TEM) analyses were conducted with a JEOL JEM-1400 electron microscope using a $120 \mathrm{kV}$ accelerating voltage. The band gap energy of the prepared samples was calculated using Kubelka-Munk equation [34]. Ultraviolet-visible diffuse reflectance spectroscopy (UV-vis DRS) was carried out using a Shimadzu 2450. The specific surface area of the catalysts was measured by BET of $\mathrm{N}_{2}$ adsorption in a Quantachrome Autosorb-6.

\section{Photocatalytic activity evaluation of $\mathrm{TiO}_{2}$ nanowires}

The photocatalytic activity test was performed using a pyrex reactor equipped with six black light lamps $(10 \mathrm{~W}, 352 \mathrm{~nm})$ as the photon source. The powder $\mathrm{TiO}_{2}$ nanowires was suspended in a $10 \%$ methanol/water mixture at a concentration of $1 \mathrm{~g} / \mathrm{L}$. A magnetic stirrer was placed at the bottom of the reactor to ensure homogeneity of the suspension during reaction. The suspensions were then flushed with Argon gas for 15 minutes to remove undesired gases. Hydrogen was analyzed by gas chromatography (GC) using a Shimadzu steel column packed with molecular sieves and an Argon carrier. 


\section{RESULTS AND DISCUSSION}

\section{The effect of sonication time on the synthesize of $\mathrm{TiO}_{2}$ nanowires}

In order to investigate the effect of sonication on the formation of $\mathrm{TiO}_{2}$ nanowires, samples were prepared using different treatments: $1 \mathrm{~h}$ sonication process followed $15 \mathrm{~h}$ hydrothermal treatment $\left(\mathrm{TiO}_{2} \mathrm{Nw}-1 \mathrm{~s}-15 \mathrm{~h}\right)$ and $15 \mathrm{~h}$ hydrothermal treatment without sonication $\left(\mathrm{TiO}_{2} \mathrm{Nw}-0 \mathrm{~s}-15 \mathrm{~h}\right)$.

Figure 1(b1) and (b2) shows hydrothermal process for 15 hours without sonication has produced nanowires morphology but not uniform. With the addition of sonication process for 1 hour before hydrothermal treatment for 15 hours produced $\mathrm{TiO}_{2}$ nanowires uniformly, it can be seen in Figure 1 ( $\mathrm{c} 1$ and $\mathrm{c} 2$ ). The results indicated that the time of formation $\mathrm{TiO}_{2}$ nanowires could be shortened by using combination of sonication and the hydrothermal process. It due to with sonication treatment the reaction of $\mathrm{KOH}$ on the surface of de-agglomerated $\mathrm{TiO}_{2}$ particles was much faster and uniform [36]. The Sonication process was promoting the intercalation of $\mathrm{K}^{+}$into titania lattices and breaking the Ti-O-Ti bonds without altering the morphology of $\mathrm{TiO}_{2}$ Degussa P25. As a result, formation trititanate sheets in hydrothermal treatment become faster than hydrothermal without sonication.
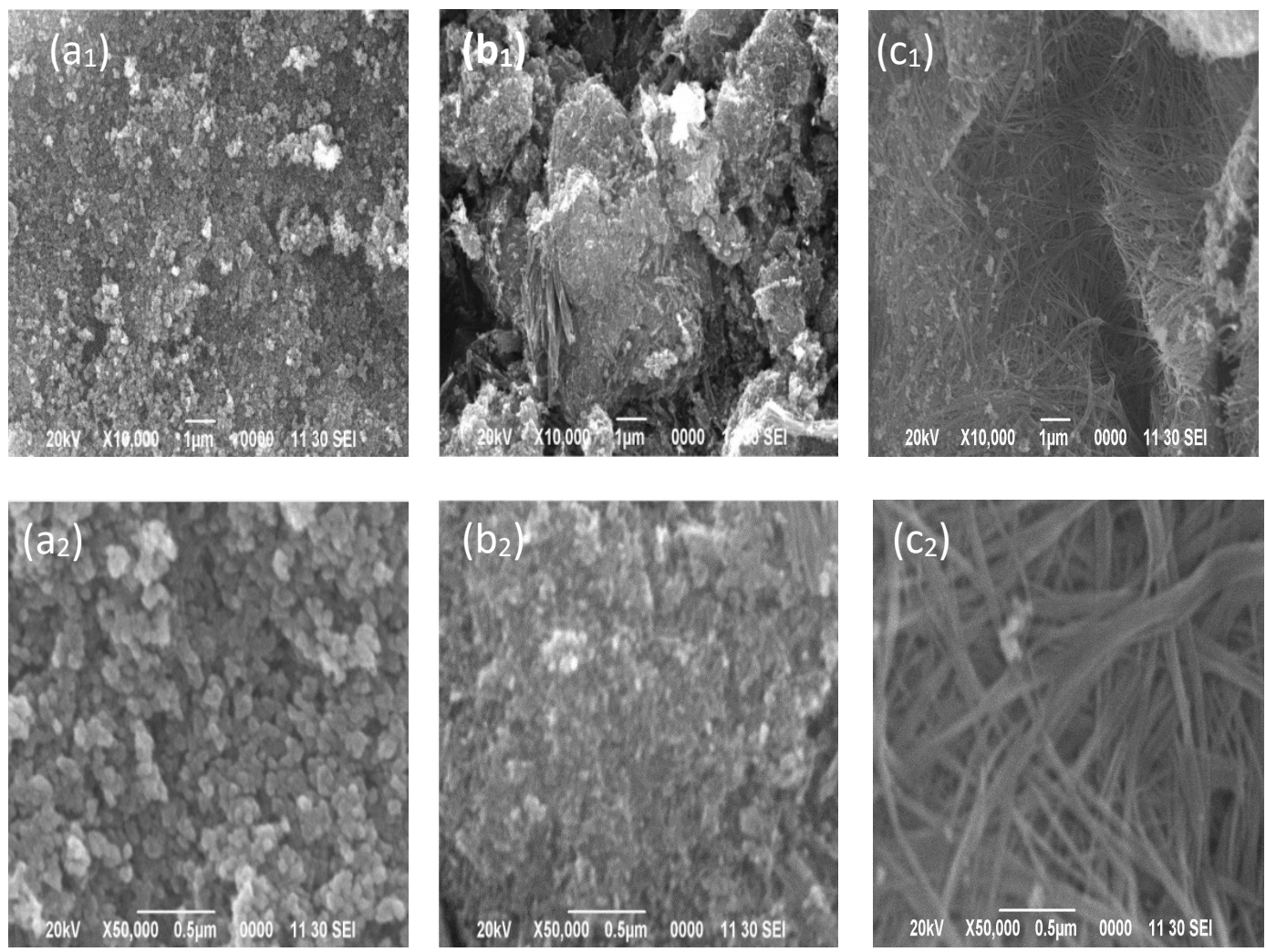

Figure 1. Scanning electron micrographs of (a) $\mathrm{TiO}_{2} \mathrm{P} 25$ and (b) $\mathrm{TiO}_{2} \mathrm{NWs}-0 \mathrm{~s}-15 \mathrm{~h}$ (c) $\mathrm{TiO}_{2}$ NWs-1s-15h. $\mathrm{a}_{1}, \mathrm{~b}_{1}, \mathrm{c}_{1}$ are images at magnification 10,000; $\mathrm{a}_{2}, \mathrm{~b}_{2}, \mathrm{c}_{2}$ are at 50,000.

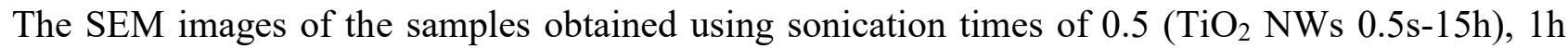
$\left(\mathrm{TiO}_{2} \mathrm{NWs} 1 \mathrm{~s}-15 \mathrm{~h}\right)$ and $2 \mathrm{~h}\left(\mathrm{TiO}_{2} \mathrm{NWs} 2 \mathrm{~s}-15 \mathrm{~h}\right)$ followed hydrothermal treatment for $15 \mathrm{~h}$ are shown at Figure 2. It shows the time of sonication greatly influenced on change in shape and morphology samples. Figure 2(a) shows the SEM image of sample subjected to sonication time of $0.5 \mathrm{~h}$. It indicated that morphology of nanowires was formed but not yet uniform. It can be seen clearly on image which higher magnification at Figure 2(a2). Figure 2(b) shows the samples were found to be completely transformed into nanowires shapes after sonication $1 \mathrm{~h}$ followed by hidrothermal. However, the longer sonication time before hydrothermal treatment was undesirable for the formation of $\mathrm{TiO}_{2}$ nanowires. The samples obtained sonication for $2 \mathrm{~h}$ were wider and had morphology similar to nanoribbons. 

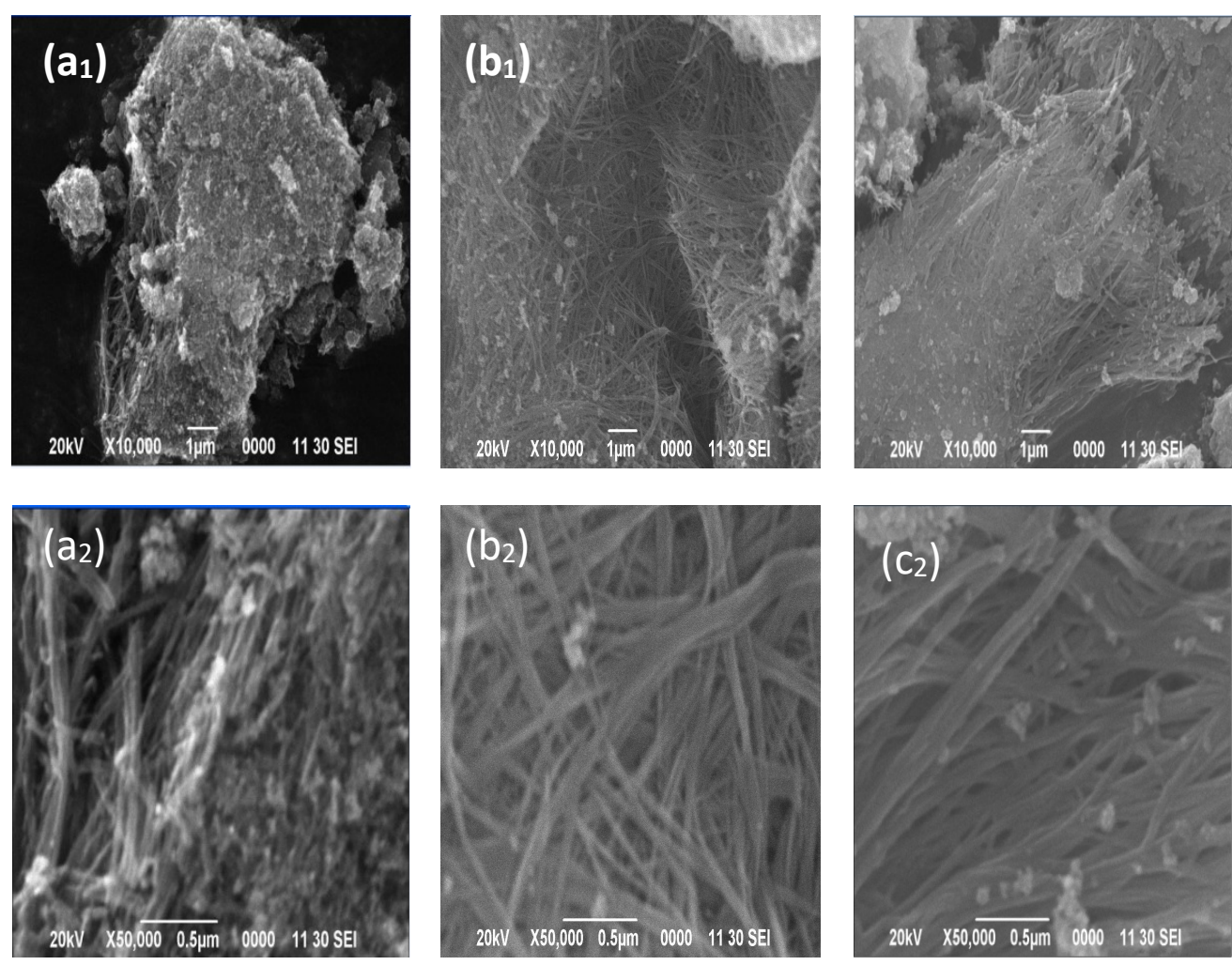

Figure 2. SEM of samples prepared using sonication and hydrothermal treatment, sonication for: (a) $\mathrm{TiO}_{2} \mathrm{NWs} 0.5 \mathrm{~s}-15 \mathrm{~h}$; (b) $1 \mathrm{~h}$; (c) $2 \mathrm{~h} . \mathrm{a}_{1}, \mathrm{~b}_{1}, \mathrm{c}_{1}$ are images at magnification 10,000; $\mathrm{a}_{2}$, $\mathrm{b}_{2}, \mathrm{c}_{2}$ are at 50,000 .

\section{Effect of hydrothermal treatment on $\mathrm{TiO}_{2}$ Nanowires formation}

The reaction time of hydrothermal treatment plays an important role in the formation of $\mathrm{TiO}_{2}$ nanowires. In or to investigate this $\mathrm{The}^{\mathrm{TiO}} 2$ nanowires was performed with sonication process for $1 \mathrm{~h}$ and continued with hydrothermal treatment for 12 hours, 15 hours and 24 hours. The SEM images of the samples are shown in Figure.3.

Figure 3(a) shows that $\mathrm{TiO}_{2}$ nanowires had formed in small amount after hydrothermal treatment for 12 hours. It was very different with the samples that produced through hydrothermal for 15 hours are shown at Figure 3(b). In this product, the morphology of $\mathrm{TiO}_{2}$ nanowires was evenly formed and had a good shape. However, the longer duration of hydrothermal treatment with sonication for 1 hour did not provide a better form of $\mathrm{TiO}_{2}$ nanowires. It can be seen clearly at Figure 3(c) that hydrothermal treatment for 24 hours generated $\mathrm{TiO}_{2}$ nanowires which a wider and had morphology similar to nanoribbons.

The formation of $\mathrm{TiO}_{2}$ nanowires occured during the hydrothermal process. Due to reaction between $\mathrm{TiO}_{2}-\mathrm{P} 25$ with $\mathrm{KOH}$ as solvent, some of Ti-O-Ti bonds of Titania crystals are broken to produce Ti-O-K and Ti-OH and layered as octatitanates $\left(\mathrm{K}_{2} \mathrm{Ti}_{8} \mathrm{O}_{17}\right)$ that are formed on the titania surface along the $\left(\begin{array}{lll}0 & 1 & 0\end{array}\right)$ lattice plans of $\mathrm{TiO}_{2}$. Their $\left(\begin{array}{lll}2 & 0 & 0\end{array}\right)$ plans may parallel to the $\left(\begin{array}{lll}0 & 1 & 0\end{array}\right)$ lattice plan of $\mathrm{TiO}_{2}$. Further hydrothermal reactions cause the nanowires to grow out along the $\left(\begin{array}{lll}0 & 1 & 0\end{array}\right)$ direction [36]. The growth of $\mathrm{TiO}_{2}$ nanowires caused by high operating temperatureand pressure in the autoclave during the hydrothermal process $\left(\mathrm{T}>130^{\circ} \mathrm{C}\right)$, it caused no tendency to form a coil like nanotubes morphology. Further growth of nanowires increased during the hydrothermal time and it caused $\mathrm{TiO}_{2}$ nanowires to grow along the direction of growing photocatalyst [38]. 

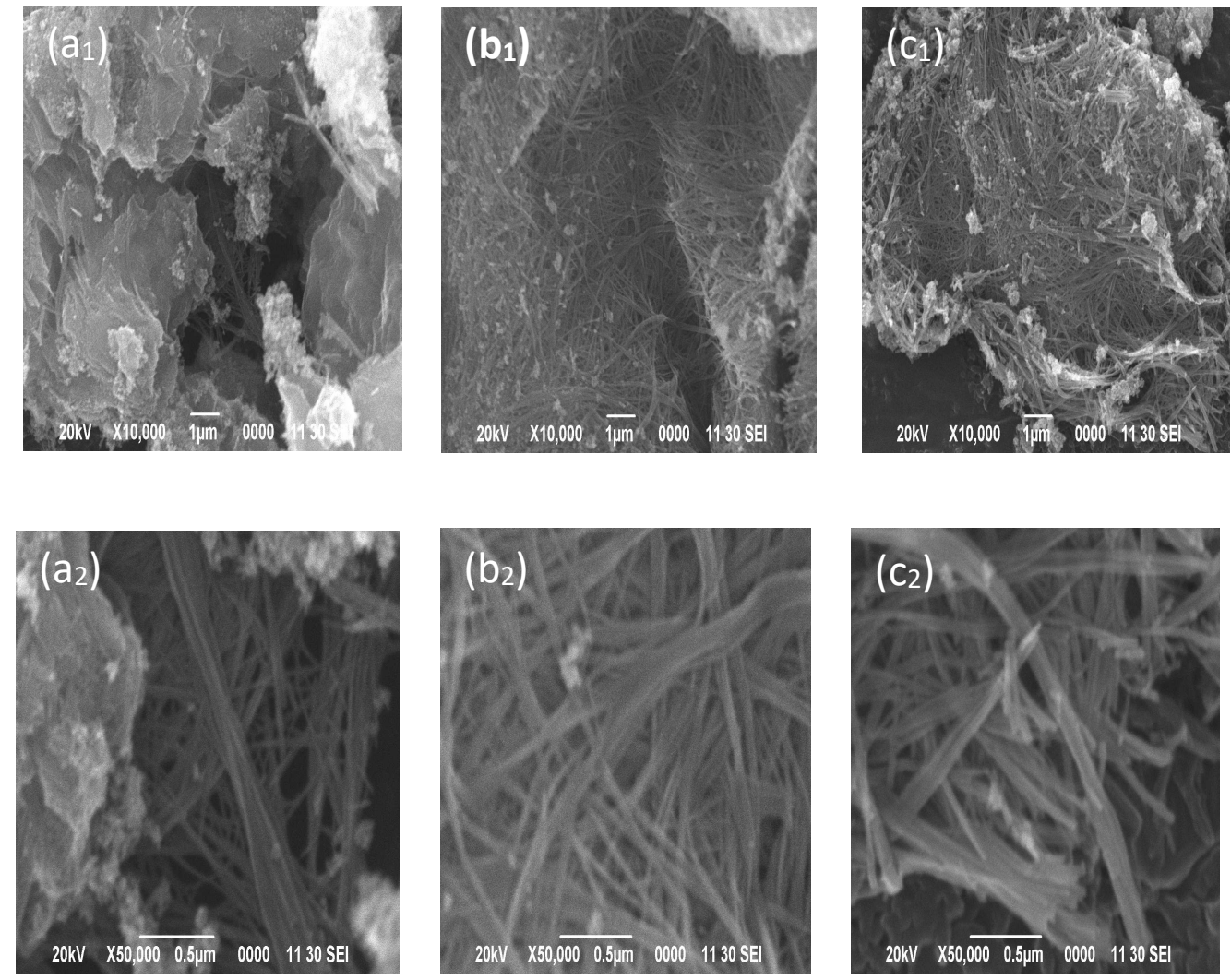

Figure 3. Scanning electron micrographs of sonication $1 \mathrm{~h}$ followed hydrothermal treatment; (a) 12 h; (b) $15 \mathrm{~h}$; (c) 24 h. a $, b_{1}, c_{1}$ are images at magnification 10,000; $a_{2}, b_{2}, c_{2}$ are at 50,000.

Figure 4 shows the Transmission electron Microscope of $\mathrm{TiO}_{2}$ nanowires from $1 \mathrm{~h}$ sonication followed 15 hydrothermal. It shows hydrothermal with $\mathrm{KOH}$ as a solvent produced wirelike morphology with a porous structure. The diameter of $\mathrm{TiO}_{2}$ nanowires was 5,7 nm.Yuan \& $\mathrm{Su}$ (2004) reported that the morphology of nanowires usually has a diameter in the range of 5-10 nm [38].
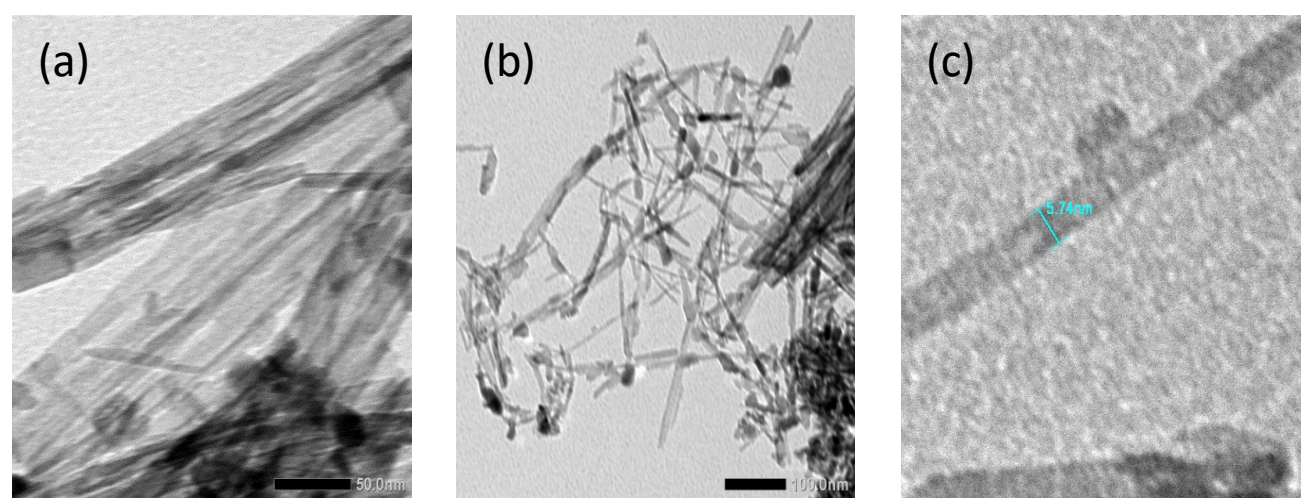

Figure 4. The transmission electron microscope of $\mathrm{TiO}_{2}$ nanowires (a) image at magnification $50 \mathrm{~nm},(\mathrm{~b})$ image at magnification $100 \mathrm{~nm}$ dan (c) diameter of $\mathrm{TiO}_{2} \mathrm{NWs}$

The morphology of the catalyst caused the significant difference of surface area. The surface area of $\mathrm{TiO}_{2}$ nanowires and nanopartikel were $115,74 \mathrm{~m}^{2} / \mathrm{g}$ and $32.77 \mathrm{~m}^{2} / \mathrm{g}$ respectively. The large surface area of $\mathrm{TiO}_{2}$ nanowires indicates this product had a porous structure. The surface area of $\mathrm{TiO}_{2}$ NWs was higher than $\mathrm{TiO}_{2} \mathrm{NW}$ which obtained by other researcher. Jitputi et al (2008) 
obtained the surface area of $\mathrm{TiO}_{2} \mathrm{NW}$ was $58,20 \mathrm{~m}^{2} / \mathrm{g}$ after hydrothermal treatment for 72 hours [15].

\section{The X- Ray Difraction of $\mathrm{TiO}_{2}$ nanowires}

The phase composition, crystallite size and crystallinity of $\mathrm{TiO}_{2}$ were reported to have a great influence on photocatalytic activity such as water splitting.

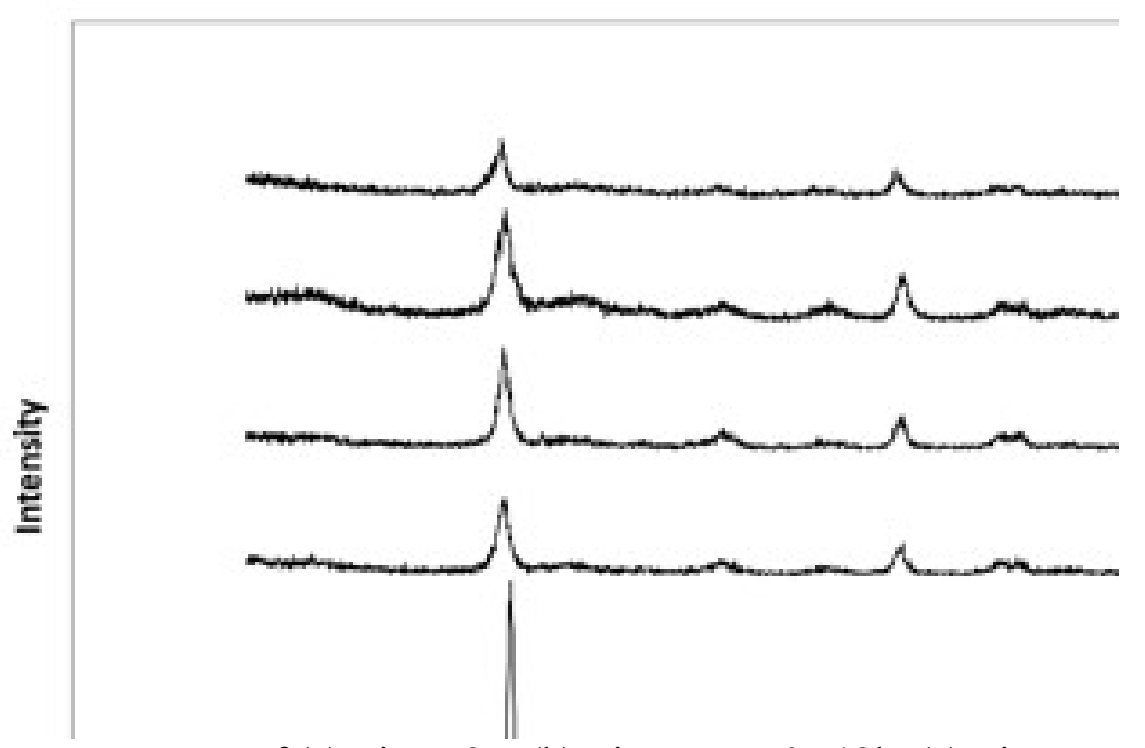

Figure 5. XRD patterns of (a) $\mathrm{TiO}_{2} \mathrm{P} 25$; (b) $\mathrm{TiO}_{2} \mathrm{NWS}-0 \mathrm{~s}-12 \mathrm{~h}$; (c) $\mathrm{TiO}_{2} \mathrm{NWs}-0.5 \mathrm{~s}-12 \mathrm{~h}$;

(d) $\mathrm{TiO}_{2}$ NWs-1s-12h; (e) $\mathrm{TiO}_{2}$ NWs-2s-12h

Therefore, the XRD analysis of $\mathrm{TiO}_{2} \mathrm{NWs}$ was conducted in this research. Figure 5 shows the XRD patterns of $\mathrm{TiO}_{2} \mathrm{P} 25$ and $\mathrm{TiO}_{2} \mathrm{NWs}$ prepared with different sonication times followed hydrothermal treatment $12 \mathrm{~h}$. The XRD patters for $\mathrm{TiO}_{2} \mathrm{NWs}$ was obtained from combination $1 \mathrm{~h}$ sonication followed by hydrothermal for various time can be seen at Figure 6 .

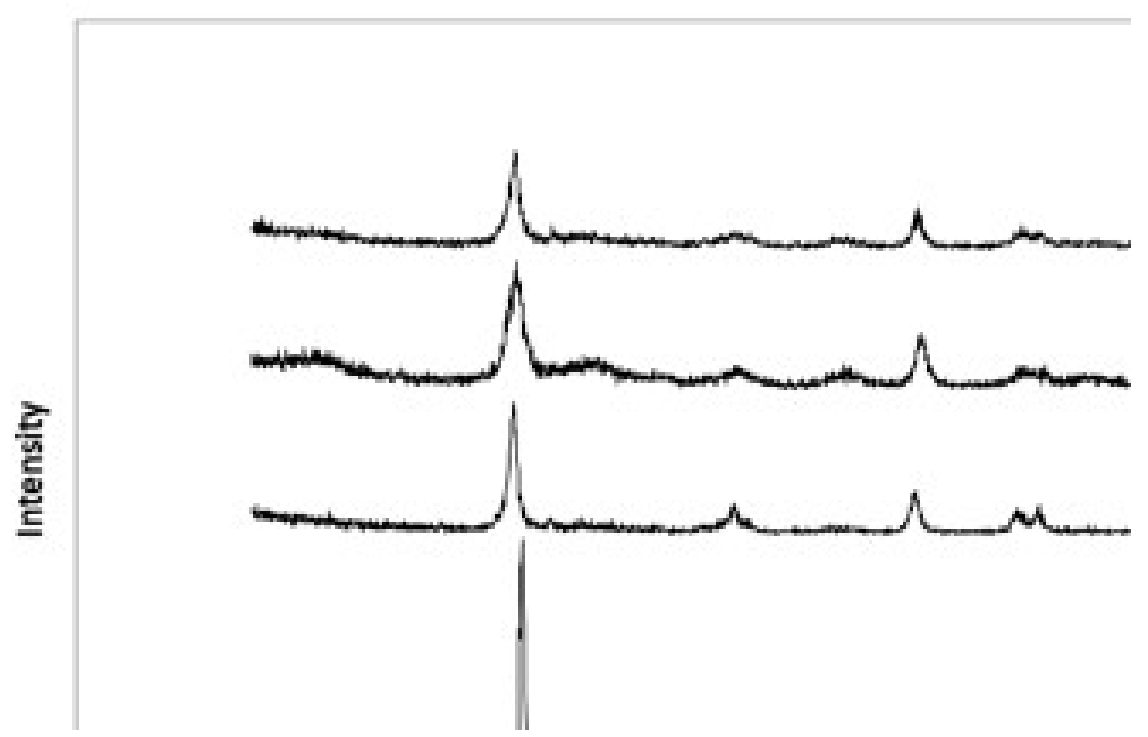

Figure 6. XRD patterns of (a) $\mathrm{TiO}_{2} \mathrm{P} 25 ; \mathrm{TiO}_{2} \mathrm{NWs} 1 \mathrm{~h}$ sonication followed hydrothermal for (b) $\mathrm{TiO}_{2} \mathrm{NWs}-1 \mathrm{~s}-12 \mathrm{~h}$; (c) $\mathrm{TiO}_{2} \mathrm{NWs}-1 \mathrm{~s}-15 \mathrm{~h}$; (d) $\mathrm{TiO}_{2} \mathrm{NWs}-1 \mathrm{~s}-24 \mathrm{~h}$ 
All products of $\mathrm{TiO}_{2}$ nanowires, both Figure 5 and Figure 6 had completely crystalline structure of anatase $\mathrm{TiO}_{2}$ but the $\mathrm{TiO}_{2}$ Degussa P25 nanoparticles consisted of mixed anatase and rutile. This was because of at hydrothermal process, $\mathrm{TiO}_{2} \mathrm{P} 25$, which had anatase and rutile phase, transformed into sodium trititanate as amorphous, only anatase phase was formed after calcination at $500^{\circ} \mathrm{C}$ [24]. The rutile phase was formed at calcination temperature above $700^{\circ} \mathrm{C}$. Similar results have been reported by many researchers, that only anatase phase was formed after calcination of hydrogen titanate nanotubes at $500^{\circ} \mathrm{C}[16,24,40,43]$.

Table 1. The crystalline size of $\mathrm{TiO}_{2} \mathrm{P} 25$ and $\mathrm{TiO}_{2}$ nanowires at various time of sonication followed by hydrothermal treatment for $12 \mathrm{~h}$

\begin{tabular}{lc}
\hline Samples & $\begin{array}{c}\text { Crystalline size } \\
(\mathrm{nm})\end{array}$ \\
\hline $\mathrm{TiO}_{2} \mathrm{P}-25$ & 18 \\
$\mathrm{TiO}_{2} \mathrm{NWs}-0 \mathrm{~s}-12 \mathrm{~h}$ & 10.16 \\
$\mathrm{TiO}_{2} \mathrm{NWs}-0.5 \mathrm{~s}-12 \mathrm{~h}$ & 11.11 \\
$\mathrm{TiO}_{2} \mathrm{NWs}-1 \mathrm{~s}-12 \mathrm{~h}$ & 15.09 \\
$\mathrm{TiO}_{2} \mathrm{NWs}-2 \mathrm{~s}-12 \mathrm{~h}$ & 13.92 \\
\hline
\end{tabular}

The Crystalline sizes of $\mathrm{TiO}_{2}$ NWs at various time sonication and hydrothermal are summarized in Table 1 and Table 3 respectivelly. Both of Tables show that all crystalline sizes off product were smaller than $\mathrm{TiO}_{2} \mathrm{P} 25$. It due to during hydrothermal process $\mathrm{TiO}_{2} \mathrm{P} 25$ transformed into amorphous sodium tritatane.

Table 2. The crystalline size of $\mathrm{TiO}_{2}$ nanowires prepared using combination $1 \mathrm{~h}$ sonication followed hydrothermal treatment at various times

\begin{tabular}{lc}
\hline Samples & $\begin{array}{c}\text { Crystalline size } \\
(\mathrm{nm})\end{array}$ \\
\hline $\mathrm{TiO}_{2} \mathrm{P}-25$ & 18 \\
$\mathrm{TiO}_{2}$ NWs-1s-12h & 15.09 \\
$\mathrm{TiO}_{2}$ NWs-1s-15h & 8.92 \\
$\mathrm{TiO}_{2}$ NWs-1s-24h & 12.72 \\
\hline
\end{tabular}

The formation of anatase phase from amorphous sodium trititanate was occurred during calcinations treatment. Table 1 and Table 2 show that both of sonication time and hydrothermal time did not affect significantly at crystallite size. It also could be seen both Figure 5 and Figure 6. It indicates the formation of crystalline was strongly affected by temperature. The higher temperature of calcinations obtained higher crystallite size, but the temperature above $500^{\circ} \mathrm{C}$ could destroy the nanotubes shape and beside that the phase of crystal changed to be rutile [42].

\section{The Diffuse Reflectance Spectroscopy of $\mathrm{TiO}_{2}$ nanowires.}

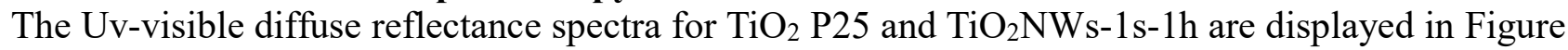
7. Band gap energy of the samples have been calculated using Kubelka-Munk equation [36]. Band gap energy is obtained by extrapolating the plot of the absorption coefficient at the $y$-axis versus energy at the $\mathrm{x}$-axis. 


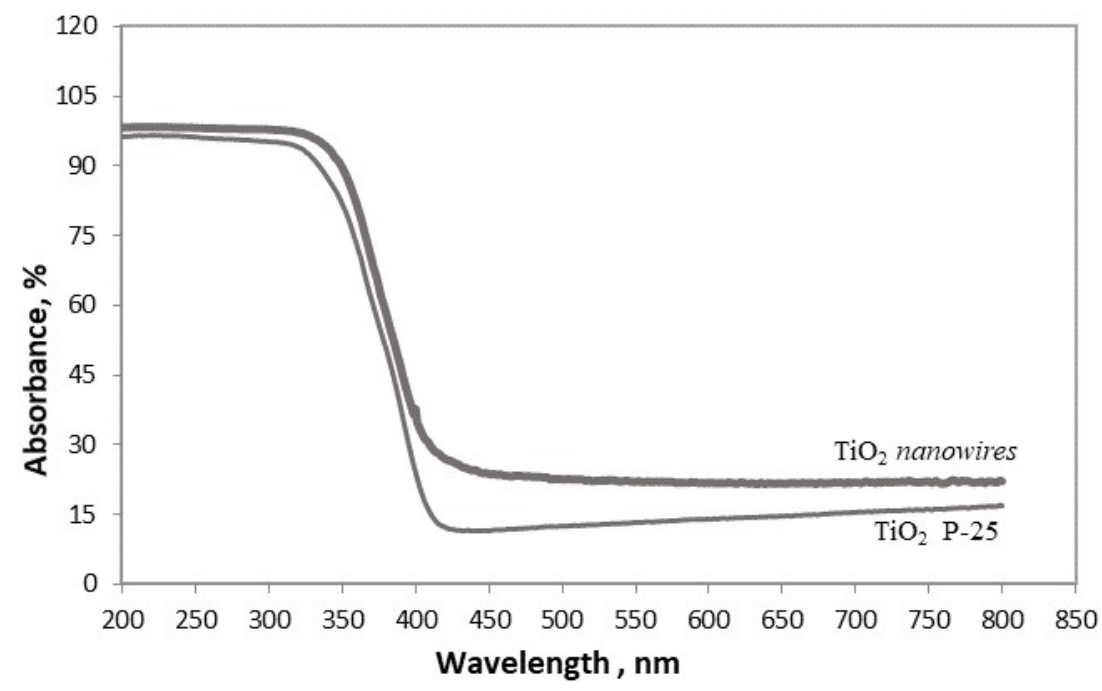

Figure 7. The Diffuse Reflectance Spectroscopy of $\mathrm{TiO}_{2}$ nanowires and $\mathrm{TiO}_{2} \mathrm{P} 25$

Figure 7 shows that spectra $\mathrm{TiO}_{2} \mathrm{P} 25$ and $\mathrm{TiO}_{2}$ Nanowires are almost same. It showed that both of $\mathrm{TiO}_{2}$ nanowires and $\mathrm{TiO}_{2} \mathrm{P} 25$ had strong UV absorption in the range $300 \mathrm{~nm}$ and $430 \mathrm{~nm}$. The band gap energy of these samples can be seen at Table 3 .

Table 3. Band gap energy of $\mathrm{TiO}_{2} \mathrm{P} 25$ and $\mathrm{TiO}_{2} \mathrm{NWs}-1 \mathrm{~s}-12 \mathrm{~h}$

\begin{tabular}{ll}
\hline Samples & Band Gap Energy, eV \\
\hline $\mathrm{TiO}_{2} \mathrm{P} 25$ & 3.05 \\
$\mathrm{TiO}_{2}$ NWs-1s-12h & 2.90 \\
\hline
\end{tabular}

As shown at Table 3, the bandgap for $\mathrm{TiO}_{2} \mathrm{P} 25$ was approximately 3.05 e, it was corresponded to the absorption of wavelength $<400 \mathrm{~nm}$. The bandgap of the $\mathrm{TiO}_{2}$ nanowires was almost same with bandgap of $\mathrm{TiO}_{2} \mathrm{P} 25$. It due to all prepared samples were crystalline $\mathrm{TiO}_{2}$ and the crystallite sizes were almost same.

\section{Effect of hydrothermal time on the $\mathrm{TiO}_{2}$ Nanowires activity}

The activity of $\mathrm{TiO}_{2}$ nanowires was evaluated by photocatalytic water splitting from aqueous methanol solution. Methanol was used as the sacrificial agent because of its ability to remove the photogenerated holes, thereby it reduces the mutual electron-hole recombination [42]. Photocatalytic water splitting by using $\mathrm{TiO}_{2}$ nanowires were obtained by combination $1 \mathrm{~h}$ sonication and hydrothermal at various time are shown at Figure. 8. For comparison we also observed the activity of $\mathrm{TiO}_{2} \mathrm{P} 25$ for hydrogen production. Figure 8 shows all prepared samples had higher activity than $\mathrm{TiO}_{2} \mathrm{P} 25$, however the production of hydrogen by $\mathrm{TiO}_{2} \mathrm{NWs} 24 \mathrm{~h}$ was almost same as $\mathrm{TiO}_{2} \mathrm{P} 25$. It indicated that morphology influenced the activity of sample for producing hydrogen. It was probably due to nanowires morphology had a higher surface area than the $\mathrm{TiO}_{2} \mathrm{P} 25$ nanoparticles. This was due to the specific surface area that also influenced the activity of the samples. The large specific area could accommodate more reactions and also could be attributed to reducing recombination. Furthermore, it might have attributed to the wires shape on the $\mathrm{TiO}_{2} \mathrm{NT}$ that allows for more effective contact between active site, photons and water molecules, which then results in better photocatalytic activity. 


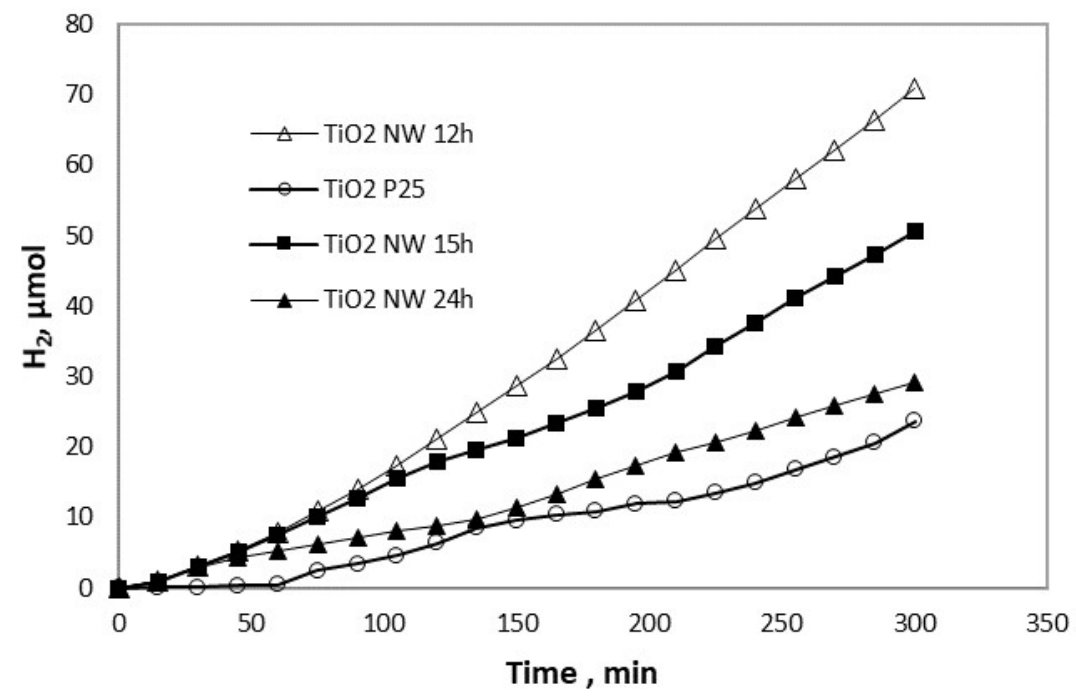

Figure 8. Hydrogen evolution over $\mathrm{TiO}_{2} \mathrm{P} 25$ and $\mathrm{TiO}_{2} \mathrm{NWs}$ at various hydrothermal treatment (Vsolution $=500 \mathrm{ml}$, catalyst $=0.5 \mathrm{~g}$, light source UV, Methanol concentration $=10 \% \mathrm{v}$ ).

Figure 8 shows $\mathrm{TiO}_{2}$ NWs was prepared using $1 \mathrm{~h}$ sonication followed $12 \mathrm{~h}$ hydrothermal exhibited higher than other $\mathrm{TiO}_{2}$ nanowires. Hydrogen was obtained using this catalyst after $5 \mathrm{~h}$ was $82 \mu$ mol. It was about two times higher than $\mathrm{TiO}_{2} \mathrm{NWs}$ from hydrothermal for $24 \mathrm{~h}$. Even though $\mathrm{TiO}_{2} \mathrm{NWs}^{-}$ $1 \mathrm{~s}-15 \mathrm{~h}$ has the best morphology of nanowires, the crystallinity of $\mathrm{TiO}_{2} \mathrm{NWs}-1 \mathrm{~s}-15 \mathrm{~h}$ is lower than that of $\mathrm{TiO}_{2}$ NWs-1s-12h. It can be seen at Table 1 and Table 2. It can be seen clearly that hydrogen production was affected to morphology and also crystallinity of catalyst.

\section{CONCLUSIONS}

$\mathrm{TiO}_{2}$ Nanowires with high crystallinity and large surface area has been successfully synthesized with faster reaction time by combination sonication and hydrothermal treatment. The morphology and crystallinity of catalysts played significant role in the specific surface area and their activity for producing hydrogen. The $\mathrm{TiO}_{2} \mathrm{NWs}$ was synthesized by $1 \mathrm{~h}$ sonication followed hydrothermal treatment for $12 \mathrm{~h}$ produced hydrogen two fold than that of $\mathrm{TiO}_{2}$ nanoparticles.

\section{ACKNOWLEDGMENTS}

The main financial support from the Ministry of Research and Technology by Hibah Insentif Dasar is gratefully acknowledged.

\section{REFERENCES}

[1] Tan SS, Zou L, Hu E. Photosynthesis of hydrogen and methane as key components for clean energy system. Science and Technology of Advanced Materials. 2007;8:89-92.

[2] Sikander U, Sufian S, KuShaari K, Chong FK. Effects of catalytic bed position of hydrogen production by methane decomposition. Journal of Mechanical Engineering and Science.2018;12:3313-3320.

[3] Fujishima A, Honda K. Electrochemical of water at a semiconductor electrode. Nature. 1972;238:37. 
[4] Slamet, Ratnawati, Gunlazuardi J, Dewi, EL, Enhanced photocatalytic activity of Pt deposited on titania nanotube arrays for the hydrogen production with glycerol as a sacrificial agent, International Journal Hydrogen Energy. 2017;42(32):24014-24025.

[5] Sun Y, Wang G, Yan $\mathrm{K}$. $\mathrm{TiO}_{2}$ nanotubes for hydrogen generation by photocatalytic water splitting in a two-compartment Photoelectrochemical cell. International Journal Hydrogen Energy. 2011;36:15502-15508.

[6] Zhang Y, Han C, Zhang G, Dionysiou DD, Nadagouda, MN. PEG assisted synthesis of crystal $\mathrm{TiO}_{2}$ nanowires with high specific surface area for enhanced photocatalytic degradation of atrazine. Chemical Engineering Journal. 2015;268:170-179.

[7] Costa LL, Prado AGS. $\mathrm{TiO}_{2}$ nanotubes as recyclable catalyst for efficient photocatalytic degradation of indigo carmine dye. Journal Photochemistry Photobiology A. 2009;201:45-49.

[8] Etgar L, Gao P, Xue Z, Peng Q, Chandiran AK, Liu B, Nazeeruddin MK, Gratzel M. Mesoscopic $\mathrm{CH}_{3} \mathrm{NH}_{3} \mathrm{PbI}_{3} / \mathrm{TiO}_{2}$ heterojunction solar cells, Journal of the American Chemical Society. 2012;134:17396-17399.

[9] Das TK, Ilaiyaraja P, Sudakar C. Template assisted Nano porous $\mathrm{TiO}_{2}$ nanoparticles: The effect of oxygen vacancy defects on photovoltaic performance of DSSC and QDSSC. Solar Energy. 2018;159:920-929.

[10] Hoffmann MR, Martin ST, Choi W, Bahnemann DW. Environmental Application of Semiconductor Photocatalysis. Chemical Reviews. 1995;95:69-96.

[11] Zhao JC, Wu TX, Wu KQ, Oikawa K, Hidaka H, Serpone N, Photoassisted degradation of Dye 3 Pollutants degradation of the cationic dye rhodamine $\mathrm{B}$ in aqueous anionic surfactant $/ \mathrm{TiO}_{2}$ dispersions under visible light irradiation: Evidence for the need of substrate adsorption on $\mathrm{TiO}_{2}$ particles. Environmental Science \& Technology. 1998;32: 2394-2400.

[12] Yetim T. Corrosion behaviour of Ag-doped $\mathrm{TiO}_{2}$ coatings on commercially pure Titanium in simulated body fluid solution. Journal of Bionic Engineering. 2016;13(2):397-405.

[13] He X, Zhang G, Wang X, Hang R, Huang X, Qin L, Tang B, Zhang X. Biocompatibility, corrosion resistance and antibacterial activity of $\mathrm{TiO} 2 / \mathrm{CuO}$ coating on Titanium. Ceramics International. 2017; 43(18):16185-16195.

[14] Chen XB and Mao SS. Titanium dioxide nanomaterials: synthesis, properties, modification and applications. Chemical Reviews. 2007;107:2891-2959

[15] Jitputti J, Yoshikazu S, Yoshikawa S. Synthesis of $\mathrm{TiO}_{2}$ nanowires and their photocatalytic activity for hydrogen evolution. Catalysis Communications. 2007;9:1265-1271.

[16] Kustiningsih I, Slamet, Purwanto WW, Synthesis of Titania Nanotubes and Titania Nanowires by Combination Sonication hydrothermal Treatment and their Photocatalytic Activity for Hydrogen Production. International Journal of Technology. 2014;5:133-141.

[17] Yang X, Liang H, Wu L, Zhang J, Huang Y, Li X, High performance carbon/silica codecorated $\mathrm{TiO}_{2}$ nanotubes for visible-light driven water splitting. Materials Research Bulletin. 2017;93:162-169.

[18] Ismail S, Lockman Z, Kian TW. Formation and photoe;ectrochemical properties of TiO2 nanotubes arrays in fluowrinatedorganic electrolyte, Journal of Mechanical Engineering and Science. 2017;11:3129-3136.

[19] Liu Z, Zhang J, Hong T, Zheng X, Guo K, Liu Z. High-efficiency nanorod-nanosheet arrays sandwich photoelectrode for photoelectrochemicl water splitting. International Journal Hydrogen Energy. 2016;41(31):13359-13367.

[20] Subramanian A, Pan Z, Li H, Zhou L, Li W, Qiu Y, Xu Y, Hou Y, Muzi C, Zhang Y. Synergistic promotion of photoelectrochemical water splitting efficiendy of $\mathrm{TiO}_{2}$ nanorods using metal-semiconducting nanoparticles. Applied Surface Science. 2017;420:631-637

[21] Xu F, Mei J, Zheng M, Bai D, Wu D, Gao Z, Jiang K. Au nanoparticles modified branched $\mathrm{TiO}_{2}$ nanorod array arranged with ultrathin nanorods for enhanced photoelectrochemical water splitting. Journal of Alloys and Compounds. 2017;693:1124-1132. 
[22] Camposeco R, Castillo S, Navarrete J, Gomez R, Synthesis, characterization and photocatalytic activity of $\mathrm{TiO}_{2}$ nanostructures: Nanotubes, nanofibers, nanowires and nanoparticles. Chemistry of Materials. 2016;266:90-101.

[23] $\mathrm{Ou} \mathrm{HH}$ and Lo SL. Review of titania nanotubes synthesized via the hydrothermal treatment: fabrication, modification and application. Separation and Purification Technology. 2007;58:179-191.

[24] Kustiningsih I, Slamet, Purwanto WW, Synthesis of $\mathrm{TiO}_{2}$ nanotubes by using combination of sonication and hydrothermal treatment and their photocatalytic activity for hydrogen evolution. Reaktor, 2015:15;205-212.

[25] Maheswari D and Venkatachalam P. Fabrication and characterization of $\mathrm{TiO}_{2}$ nanotubes by hydrothermal method in the design of DSSC. Applied Solar Energy. 2013;49:93-97.

[26] Bavykin DV, Friedrich JM, Walsh FC. Protonated titanates and $\mathrm{TiO}_{2}$ nanostructured materials: synthesis, properties and application. Advanced Materials. 2006;18: 2807-2824.

[27] Borbón-Nuñez HA, Dominguez D, Muñoz-Muñoz F, Lopez J, Romo-Herrera G, Tiznad H. Fabrication of hollow $\mathrm{TiO}_{2}$ nanotubes through atomic layer deposition and MWCNT templates. Powder Technology, 2017;308: 249-257.

[28] Kasuga T, Hiramatsu M, Hoson A, Sekino T, Nihara K. Formation of titanium oxide nanotubes. Langmuir. 1998;14:3160-3163.

[29] Zwilling V, Aucouturier M, Darque-Ceretti E. Anodic oxidation of titanium and TA6V alloy in chromic media, An electrochemical approach, Electrochimica Acta. 1999; 45:921.

[30] Gong D, Grimes CA, Varghese OK, Hu W, Singh RS, Chen Z, Dickey EC. Titanium oxide nanotube arrays prepared by anodic oxidation, Journal of Material Research. 2001;16:3331.

[31] Lin T, Liao M, Zhao S, Fan $\mathrm{H}$, Zhu X. Anodic $\mathrm{TiO}_{2}$ nanotubes produced under atmospheric pressure and in vacum conditions. Ceramics International, 2018;44(2):1764-1770.

[32] Dong Z, Ding D, Lia T, Ning C. Facile fabrication of Si-doped $\mathrm{TiO}_{2}$ nanotubes photoanode for enhanced photoelectrochemical hydrogen generation. Applied Surface Science. 2018;436:125-133.

[33] Wang FM, Shi ZS, Gong F, Jiu JT, Adachi M, Morphology control of anatase $\mathrm{TiO}_{2}$ by surfactant-assisted hydrothermal method. Chinese Journal of Chemical Engineering.2007; 15:754-759.

[34] Yun G, Song YG, Ahn BE, Lee SK, Heo J, Ahn KS, Kang SH, Beneficial surface passivation of hydrothermally grown $\mathrm{TiO}_{2}$ nanowires for solar water oxidation. Applied Surface Science. 2016;366:561-566

[35] Weller H. Colloidal semiconductor Q-particles chemistry in the transition region between solid state and molecules. Angewandte Chemie International Special Edition in English. 1993;32:41-53.

[36] Yoong LS, Chong FK, Duta BK, Development of Copper and doped $\mathrm{TiO}_{2}$ photocatalyst for hydrogen production under visible light. Energy. 2009;34:1652-1661.

[37] Viriya-Empikul N, Charinpanitkul T, Sano N, Faungnawakij K, Tanthapanichakoon W. Effect of reaction temperature and sonication pretreatment in the hydrothermal process on the morphology of titanate nano-structure. Journal of Chemical Engineering of Japan. 2009; s234-s237.

[38] Yuan ZY and Su BL. Titanium Oxide nanotubes, nanofibers and nanowires. Colloid Surface A. 2004;241:173-183.

[39] Yu J, Yu H, Cheng B, Trapalis C. Effect of calcination temperature on the microstructures and photocatalytic activity of titanate nanotubes. Journal of Molecular Catalyst. A. 2006;249:135142.

[40] Sun XM and Li YD. Synthesis and characterization of ion exchangeable titanate nanotubes. Chemistry- A European Journal. 2003;9:2229. 
[41] Pang YL, Abdullah AZ, Bhatia S. Effect of annealing temperature on the characteristics, sonocatalytic activity and reusability of nanotubes $\mathrm{TiO}_{2}$ in the degradation of Rhodamine $\mathrm{B}$. Applied Catalysis B: Environmental. 2010;100:393-402.

[42] Yu J, Yu H, Cheng B, Trapalis C. Effect of calcination temperature on the microstructures and photocatalytic activity of titanate nanotubes, Journal of Molecular Catalyst A. 2006;249:135142.

[43] Bavykin DV, Gordeev SN, Moskalenko AV, Lapkin AA, Walsh FC. Apparent two-dimensional behavior of $\mathrm{TiO}_{2}$ nanotubes revealed by light absorption and luminescence. The Journal of Physical Chemistry B. 2005;109:8565-8569. 